\title{
PENGARUH LATAR BELAKANG PENDIDIKAN DAN TINGKAT PEMAHAMAN MATA KULIAH ASWAJA (AHLI SUNNAH WAL JAMAAH) TERHADAP SIKAP TOLERAN PADA LIBERALISME DI KALANGAN MAHASISWA FAKULTAS TARBIYAH IAI SUNAN GIRI BOJONEGORO
}

\author{
Yogi Prana Izaa \\ Institut Agama Islam Sunan Giri Bojonegoro \\ Zherifzizi@gmail.com
}

\begin{abstract}
ABSTRAK
"Nahdlatul Ulama merupakan organisasi yang memiliki citra moderat. Salah satu indikasinya adalah nilai-nilai Islam yang dirumuskan dalam kerangka berfikir menurut ASWAJA (Ahli Sunnah Wal Jamaah) NU. Diantaranya adalah tawassuth (tengahtengah), i'tidāl(berkeadilan), tasāmuh(toleran), tawāzun (seimbang/harmoni) dan amar ma'ruf nahi munkar. Semua lembaga pendidikan yang berafiliasi kepada Nahdlatul Ulama, wajib mengajarkan materi ASWAJA kepada peserta didik, tidak terkecuali IAI Sunan Giri Bojonegoro dengan nama mata kuliah ASWAJA. Namun demikian, disinyalir bahwa tidak sedikit mahasiswa yang memiliki sikap berbeda (toleran/moderat dan intoleran/fanatik) terhadap aliran pemikiran liberal. Oleh karena itu, penelitian ini akan mengungkap lebih jauh tentang sikap toleran mahasiswa terhadap liberalisme. Penelitian ini mengambil sampel dari mahasiswa Fakultas Tarbiyah Prodi Pendidikan Agama Islam sebanyak 40 orang. Data diperoleh melalui dokumen, teknik tes dan kuisioner. Analisis data penelitian menggunakan desain varian/faktorial 2 jalur (two way analysis of variant). Hasil penelitian menunjukkan bahwa sikap toleransi terhadap Liberalisme dipengaruhi oleh latarbelakang pendidikan baik pesantren maupun non pesantren. Demikian juga, pemahaman mata kuliah ASWAJA ikut mempengaruhi sikap toleransi terhadap Liberalisme. Namun demikian, tidak terdapat hubungan interaktif antara latarbelakang pendidikan pesantren dan non pesantren dengan tingkat pemahaman mata kuliah ASWAJA. Artinya, meskipun latarbelakang pendidikan dan tingkat pemahaman ASWAJA memberikan kontribusi yang signifkan pada sikap toleran Liberalisme tetapi antara keduanya tidak terdapat interaksi, sehingga tidak akan memberikan kontribusi yang signifikan pada latarbelakang pendidikan (pesantren dan non pesantren) dan tingkat pemahaman ASWAJA."
\end{abstract}

Kata kunci : ASWAJA, Toleransi, Liberalisme

\section{Pendahuluan}

Institut Agama Islam (IAI) Sunan Giri merupakan perguruan tinggi yang diselenggarakan oleh Nadlatul Ulama (NU) melalui Badan Penyelenggara Perguruan Tinggi Nahdlatul Ulama (BPPT-NU) kabupaten. Sebagai perguruan tinggi dibawah naungan NU, nilai-nilai ajaran Islam yang telah dirumuskan oleh organisasi 
diinternalisasikan kedalam proses belajar mengajar melalui mata kuliah muatan institusi. Diantara mata kuliah yang wajib ada pada seluruh fakultas adalah ASWAJA (Ahli Sunnah wal Jamaah).

ASWAJA tidak lain adalah aliran atau paham keagamaan seperti aliran dan paham keagamaan yang lain seperti Liberalisme, Syi'ah, Salafisme, dan lain-lain. Paham ASWAJA yang dirumuskan oleh NU mempunyai karakteristik yang berbeda dengan paham ASWAJA yang lainnya. Secara garis besar, doktrin ASWAJA NU meliputi tiga aspek, yaitu akidah/tauhid yang didasarkan pada akidah Asy'ariyah dan Maturidiyah, syariah (fiqh) yang didasarkan pada empat madzbah fiqh (Hanafi, Maliki, Syafi'i dan Hanbali), dan tasawuf yang diambil dari tasawuf Imam Junaid dan al-Ghozali (Muchtar, $2007: 3)$.

Selain doktrin dengan tiga aspek tersebut diatas, ASWAJA NU juga merumuskan nilai-nilai ajaran Islam yang menjadi kerangka berfikir organisasi Nahdlatul Ulama. Setidaknya ada lima kerangka berfikir yang merupakan ciri khas dari ASWAJA ala NU : 1) tawassuth, yaitu moderat baik dalam doktrin maupun sikap dan perilaku; 2) itidāl (berkeadilan); 3) tasāmuh, yaitu sikap toleran, tenggang rasa, tidak ekstrim, bersikap akomodatif, bisa menerima perbedaan pendapat; 4) tawāzun, yaitu harmoni, seimbang, tidak bersikap apriori dan menjaga kestabilan; dan 5) amar ma'ruf nahi munkar, yaitu menjalankan perintah-Nya dan menjauhi larangan-Nya (Muchtar, 2007: 56).

Kerangka berfikir organisasi diatas disebut juga Fikrah Nahdliyah yaitu sebuah paradigma yang didasarkan pada paham ASWAJA yang dijadikan landasan berpikir NU (Khiththah Nahdliyah) untuk menentukan arah perjuangan dalam rangka ishlāh alummah (perbaikan umat) (Navis dkk, 2012: 167). Tetapi pada perjalanannya, "perbaikan umat" ini menghadapi berbagai rintangan yang menguji sikap toleransi. Di masyarakat aliran-aliran keagamaan yang bersebrangan juga mengusung slogan "perbaikan umat" sehingga acapkali terjadi benturan. Diantara aliran yang kerap berbenturan dengan NU dan sedang berkembang adalah Liberalisme.

Kiranya menarik untuk diteliti, sejauhmana mata kuliah ASWAJA berpengaruh terhadap sikap mahasiswa terhadap Liberalisme. Namun demikian mata kuliah ASWAJA mungkin bukan satu-satunya faktor penting yang dapat mempengaruhinya terhadap sikap 
mahasiswa terhadap Liberalisme. Karena boleh jadi, latar belakang pendidikan mahasiswa juga dapat menjadi faktor penting pembentukan sikap tersebut. Mereka memilki latar belakang pendidikan semasa MA/SMA yang berbeda-beda. Diantara mereka ada yang alumni pesantren dan bahkan masih tinggal dipesantren. Sebagian yang lain menempuh pendidikan formal non pesantren.

Latar belakang pendidikan yang berbeda mungkin saja akan menghasilkan sikap yang berbeda terhadap Liberalisme. Oleh karena itu, penelitian ini akan berusaha mengungkap lebih jauh tentang pengaruh latar belakang pendidikan mahasiswa terhadap sikap mereka terhadap Liberalisme.

Berdasarkan asumsi-asumsi diatas, penelitian ini ditujukan untuk mengungkap pengaruh mata kuliah ASWAJA dan latar belakang pendidikan terhadap sikap mahasiswa terkait toleransi pada Liberalisme di kalangan mahasiswa Fakultas Tarbiyah IAI Sunan Giri Bojonegoro.

\section{Deskripsi Teori}

Deskripsi teori ini akan menjelaskan tiga variabel pokok penelitian, yaitu : (1) Latar Belakang Pendidikan mahasiswa $\left(\mathrm{X}_{1}\right)$. (2) Pemahaman Mata Kuliah ASWAJA $\left(\mathrm{X}_{2}\right)$. (3) Sikap toleransi terhadap aliran salfisme $(\mathrm{Y})$.

1. Latar Belakang Pendidikan Mahasiswa.

Latar belakang pendidikan mahasiswa di fakultas Tarbiyah IAI Sunan Giri secara garis besar dapat dikelompokkan menjadi dua ; pesantren dan non pesantren. Pada umumnya, mahasiswa non pesantren berasal dari madrasah aliyah dan sekolah umum (SMA dan SMK) yang bukan berbasis pesantren. Sedangkan mahasiswa dengan latar belakang pendidikan pesantren, 90 persen berasal dari sekolah yang berbasis pesantren dengan sistem integral yang mewajibkan peserta didik tinggal (mondok) di pesantren atau pesantren memberikan fasilitas pemondokan bagi yang berminat (optional). Terdapat sekitar 10 persen mahasiswa yang latar belakang pendidikanya adalah sekolah berbasis pesantren namun memilih tinggal dirumah orang tuanya. 
Oleh karena itu, maksud latar belakang pendidikan pesantren dalam penelitian ini adalah mahasiswa yang lulus sekolah dengan basis pesantren dan tinggal (mondok) didalamnya. Sedangkan yang non pesantren adalah alumnus madrasah aliyah yang tidak berbasis pesantren dan sekolah umum (SMA dan SMK). Kedua jenis mahasiswa tersebut mendapatkan materi ASWAJA di fakultas tarbiyah IAI Sunan Giri Bojonegoro pada semester gasal 2015/2016.

\section{Pemahaman Mata Kuliah ASWAJA}

Mata kuliah ASWAJA di Institut Agama Islam termasuk kategori mauatan institusi. Artinya, bersifat wajib pada seluruh fakultas. Dalam buku Silabus Kurikulum Fakultas Tarbiyah IAI Sunan Giri Bojonegoro, mata kuliah ini mempunyai bobot 2 sks dengan kode MKK 20031. Mata kuliah ini bermaksud memberikan pemahaman kepada mahasiswa tentang paham ahli sunnah wal jamaah an-nadhliyah. Standar kompetensinya adalah mahasiswa dapat : a. Memahami seluk-beluk paham ASWAJA. b. Mampu menjelaskan manhaj fikrah nadhliyah. c. Mampu menerangkan alasan NU memilih teologi As'ariyahMaturidiyah dan bermadzhab empat d. Mampu bersikap sesuai ciri-ciri fikrah nahdliyah (IAI Sunan Giri : 2010).

Pemahaman pada Mata Kuliah ASWAJA dikelompokkan dalam dua kategori, yaitu toleran dan intoleran. Mahasiswa yang masuk dalam ketegori toleran adalah mereka yang dalam proses perkuliahan tidak memojokkan dan tidak mencemooh aqidah atau teologi aliran lain yang bersebrangan. Mahasiswa yang toleran cenderung lebih terbuka menyampaikan pendapat, komentar, pertanyaan bahkan kritik kepada dosennya maupun temannya ketika sedang berdiskusi di kelasnya. Sedangkan mahasiswa yang dikategorikan sebagai intoleran adalah mereka yang tidak mau menerima pendapat orang lain, tertutup, cenderung mengkalim kebenaran pendapat dirinya dan kelompoknya, tidak suka menerima kritik, dan tidak dialogis.

Sikap toleran atau intoleran mahasiswa dalam proses perkuliahan mungkin saja dapat mempengaruhi sikapnya terhadap subyek tertentu. Dalam konteks ini, 
pemahaman pada mata kuliah ASWAJA akan berpengaruh pada sikapnya terhadap Liberalisme.

3. Sikap Toleransi Terhadap Liberalisme

Kamus Umum Bahasa Indonesia menjelaskan toleransi sebagai kelapangan dada dalam arti suka kepada siapapun, membiarkan orang berpendapat atau berpendirian lain, tak mau mengganggu kebebasan berpikir dan berkeyakinan lain. Dalam bahasa Inggris bisa disebut tolerance, tolerantion (kesabaran), indulgence (sesuai kata hati), forbearance (mampu menahan diri), leniency (kemurahan hati, bersifat pengampun), mercy (belas kasihan) dan kindness (kebaikan).

Sedangkan dalam khasāis Fikrah Nahdliyah, Tasāmuh artinya bahwa Nahdlatul Ulama senantiasa dapat hidup berdampingan secara damai dengan pihak lain walaupun akidah, cara pikir, dan budanya berbeda (Navis dkk, 2012: 169). Menurut KH. Salahuddin Wahid, toleransi ialah konsep untuk menggambarkan sikap saling menghormati dan saling bekerjasama di antara kelompok-kelompok masyarakat yang berbeda secara etnis, bahasa, budaya, politik maupun agama. Karena itu toleransi merupakan konsep mulia yang sepenuhnya menjadi bagian organik dari ajaran agama-agama, termasuk Islam (Wahid, 2011: 7).

Adapun Liberalisme adalah sebuah istilah asing yang diambil dari bahasa Inggris, yang berarti kebebasan. Kata ini kembali kepada kata "liberty" dalam bahasa Inggrisnya, atau "liberte" menurut bahasa Perancis, yang bermakna bebas (al-Khurasyi,2010: 12). Diantara prinsip-prinsip Liberalisme dalam agama Islam adalah sebagai berikut :

Pertama, liberalisme al-Qur'an yaitu mengangap bahwa bahasa al-Quran sederajat dengan hakikat wahyu, namun isi dan makna pewahyuan pada dasarnya tidak bersifat harfiah-verbal, maka diperlukan upaya pemahaman.

Kedua, liberalisme syariat, yaitu merubah hukum-hukum agama Islam sehingga dapat disesuaikan dengan perkembangan zaman. Oleh sebab itu 
pemahaman al-Quran harus disesuaikan dengan perkembangan zaman sesuai dengan lingkungan budaya apapun, sebagaimana (pada saat turunnya)itu disesuaikan dengan kepentingan lingkungan Semenanjung Arab (A'la, 2003: xi).

Ketiga, Liberalisasi akidah dilakukan dengan menyebarkan faham Pluralisme agama, yaitu faham yang meyakini bahawa semua agama adalah sama-sama benar, dan merupakan jalan untuk menuju kepada Tuhan yang sama (Thaha, 2010: 65).

\section{Pengaruh Latar Belakang Pendidikan Mahasiswa terhadap Liberalisme}

Liberalisme sebagai aliran yang tengah menunjukkan eskistensinya di Indonesia mendapatkan reaksi dan respon yang sangat beragam di kalangan masyarakat Muslim, termasuk mahasiswa. Ada reaksi dan respon yang positif dan ada pula yang negatif. Reaksi dan respon positif berupa penerimaan atau paling tidak, tidak memojokkan dan negatif berupa penolakan dan juga perlawanan. Karena gerakan Liberalisme banyak mengusung tema-tema yang berlawanan dengan arus mainstream.

Pada umumnya, mahasiswa berlatar belakang pendidikan pesantren memilki dasar dan ilmu keislaman yang lebih banyak dan memadai dibanding mahasiswa yang hanya menempuh pendidikan formal. Sebab jam pelajaran agama Islam di sekolah formal tentu lebih sedikit di banding pondok pesantren yang memang mengkhususkan diri di bidang pendalaman agama Islam. Karena perbedaan-perbedaan tersebut maka tidak tertutup kemungkinan sikap terhadap Liberalisme di kalangan mereka juga berbeda.

\section{Pengaruh Pemahaman Mahasiswa pada Mata Kuliah ASWAJA terhadap Liberalisme}

Pemahaman terhadap Mata kuliah ASWAJA, memungkinkan seorang mahasiswa yang telah menempuhnya dapat memilki sikap yang terbuka (open mindedness). Ciri-ciri seseorang yang memiliki sikap terbuka adalah 1) biasanya menilai pesan secara obyektif, dengan menggunakan data dan keajegan logika, 2) orang terbuka rata-rata mampu membedakan sesuatu dengan mudah, mampu melihat suasana-suasana, 3) orang yang bersifat terbuka lebih banyak berorientasi pada isi (content) ketimbang orangnya, bungkus atau polesan-polesannya 4) keempat, orang ini mau mencari informasi dari 
berbagai sumber, tidak hanya puas dengan satu nara sumber, 5) kelima, ia lebih profesional dan bersedia tanpa malu malu untuk mengubah kepercayaan, keayakinannya, pendapatnya, jika memang terbukati itu salah (Rakhmat,2008: 55).

Dengan demikian, orang yang mempunyai sikap terbuka berpotentsi untuk toleran dan tidak diskriminatif dan semua ciri-ciri diatas sudah sesuai dengan tujuan mata kuliah ASWAJA yang menjadi dasar dari fikrah nahdliyah. Oleh karena itu juga berarti bahwa potensi seorang mahasiswa yang mengambil mata kuliah ASWAJA untuk menerima secara positif terhadap aliran yang bersebrangan lebih besar, termasuk terhadap Liberalisme.

Hanya saja mahasiswa memiliki tingkat pemahaman yang berbeda terhadap mata kuliah tersebut. Sebab di antara mereka ada yang moderat, tetapi juga ada yang fanatik. Dua karakter ini akan menghasilkan sikap yang berbeda terhadap toleransi pada Liberalisme. Mereka yang moderat sesuai dengan spirit ASWAJA dengan keterbukaanya sebenarnya sebagaimana dijelaskan di atas, akan lebih terbuka terhadap wacana-wacana aliran keagamaan dalam Islam dan toleran.

Sedangkan mahasiswa yang fanatik cenderung intoleran, Berbeda dengan mereka yang berfikiran moderat, mahasiswa yang berkarakter fanatik akan sulit menerima pemikiran dan ajaran-ajaran yang sudah "mapan" seperti tidak bermadzhab dalam liberalisasi syariah. Sebab mereka cenderung menganggap bahwa ajaran Islam sebagaimana ditawarkan dalam Liberalisme jelas bertentangan dengan ajaran dan keyakinan ASWAJA.

\section{Pengaruh Interaksi antara Latar Belakang Pendidikian Mahasiswa dan Pemahamannya pada Mata Kuliah ASWAJA pada Sikap Toleran terhadap Liberalisme}

Variasi-variasi interaksi akan banyak ditemukan di sini. Jika mahasiswa dengan latar belakang pendidikan pesantren memilki sikap yang berbeda dengan yang non pesantren, maka latar belakang pendidikan juga mempengaruhi tingkat pemahaman yang berbeda terhadap mata kuliah ASWAJA. Mahasiswa dengan latar belakang pesantren telah memilki keyakinan agama yang kuat dengan pahamnya itu. Mahasiswa dari 
kalangan pesantren mengikuti perkuliahan ASWAJA hanya untuk syarat formalitas menghabiskan SKS. Sehingga semestinya lebih bersifat moderat dan toleran.

\section{Perumusan Hipotesis}

Dari dasar pemikiran dan kerangka teoritis tentang hubungan pengaruh latar belakang pendidikan pesantren $\left(\mathrm{X}_{1}\right)$ dan non pesantren $\left(\mathrm{X}_{2}\right)$ dengan toleransi kepada aliran liberalisme (Y), maka dapat dirumuskan hipotesis sebagai berikut :

a. Terdapat perbedaan sikap toleransi antara mahasiswa yang berlatar belakang pendidikan pesantren dan Non-pesantren terhadap sikap toleran terhadap liberalisme

b. Terdapat perbedaan sikap toleransi terhadap aliran liberalisme dikalangan mahasiswa yang tingkat pemahamanya moderat dan fanatik

c. Terdapat interaksi sikap toleransi antara tingkat pemahaman mata kuliah dengan latarbelakang pendidikan

\section{METODOLOGI}

Lokasi penelitian di Institut Agama Islam Sunan Giri Bojonegoro, dimana waktu penelitiannya selama dua bulan yakni bulan September hingga Desember 2016.

Populasi dalam suatu penelitian merupakan kumpulan individu atau obyek yang merupakan sifat-sifat umum. Arikunto (2010: 173) menjelaskan bahwa populasi adalah seluruh subjek penelitian. Penulis menetapkan populasi dalam penelitian ini adalah mahasiswa-mahasiswa semester 1 fakultas Tarbiyah IAI Sunan Giri Bojonegoro.

Namun untuk mewakili populasi yang berjumlah 102 orang, dibuatlah sampel dengan jumlah 40 orang untuk mengangkat kesimpulan penelitian. Pengambilan sampel mengguakan teknik purposive sampling. Mengenai hal ini, Sugiyono (2010: 85) mengatakan bahwa teknik penentuan sampel dilakukan dengan pertimbangan tertentu. Artinya, setiap subyek yang diambil dari populasi dipilih dengan sengaja berdasarkan tujuan dan pertimbangan tertentu. Tujuan dan pertimbangan sampel penelitian ini adalah sampel tersebut mendapatkan pengajaran mata kuliah ASWAJA secara keseluruhan dengan latar belakang pendidikan yang berbeda, pesantren dan non pesantren 
Data penelitian diperoleh dengan menggunakan dokumen, teknik tes dan kuisioner. Dokumen digunakan untuk menggali data tentang latar belakang pendidikan mahasiswa $\left(\mathrm{X}_{1}\right)$. Sementara untuk menjaring data tentang pemahaman mahasiswa terhadap mata kuliah ASWAJA $\left(\mathrm{X}_{2}\right)$ menggunakan teknik tes. Kuisioner digunakan untuk mengetahui sikap mahasiswa terhadap aliran liberalisme (Y).

Untuk menentukan apakah perbedaan nilai rerata antara kelompok tersebut lebih besar daripada galat sampling yang diharapkan, maka perbandingan tersebut dilakukan dengan menggunakan analisis varian (Hadjar, 2014: 277). Oleh karena itu, untuk mengetahui hipotesis sesuai atau tidak, maka data selanjutnya diolah menggunakan analisis varian (ANAVA) dua jalur.

\section{Hasil Penelitian}

\section{Data tentang Sikap Mahasiswa terhadap Aliran Liberalisme sebagaimana berikut:}

\section{Tabel 1.}

Skor Sikap Mahasiswa terhadap Liberalisme ditinjau dari Latar Belakang Pendidikan dan Pemahaman Mata Kuliah ASWAJA

\begin{tabular}{|c|c|c|c|c|c|}
\hline NO & A & B & AB & Y & $\mathrm{Y}^{2}$ \\
\hline 1 & 1 & 1 & 11 & 70 & 4900 \\
\hline 2 & 1 & 1 & 11 & 68 & 4624 \\
\hline 3 & 1 & 1 & 11 & 66 & 4356 \\
\hline 4 & 1 & 1 & 11 & 67 & 4489 \\
\hline 5 & 1 & 1 & 11 & 50 & 2500 \\
\hline 6 & 1 & 1 & 11 & 60 & 3600 \\
\hline 7 & 1 & 1 & 11 & 67 & 4489 \\
\hline 8 & 1 & 1 & 11 & 69 & 4761 \\
\hline 9 & 1 & 1 & 11 & 68 & 4624 \\
\hline 10 & 1 & 1 & 11 & 67 & 4489 \\
\hline
\end{tabular}


Yogi Prana Izza

\begin{tabular}{|c|c|c|c|c|c|}
\hline 11 & 1 & 2 & 12 & 70 & 4900 \\
\hline 12 & 1 & 2 & 12 & 76 & 5776 \\
\hline 13 & 1 & 2 & 12 & 74 & 5476 \\
\hline 14 & 1 & 2 & 12 & 76 & 5776 \\
\hline 15 & 1 & 2 & 12 & 78 & 6084 \\
\hline 16 & 1 & 2 & 12 & 71 & 5041 \\
\hline 17 & 1 & 2 & 12 & 73 & 5329 \\
\hline 18 & 1 & 2 & 12 & 70 & 4900 \\
\hline 19 & 1 & 2 & 12 & 72 & 5184 \\
\hline 20 & 1 & 2 & 12 & 70 & 4900 \\
\hline 21 & 2 & 1 & 21 & 71 & 5041 \\
\hline 22 & 2 & 1 & 21 & 73 & 5329 \\
\hline 23 & 2 & 1 & 21 & 77 & 5929 \\
\hline 24 & 2 & 1 & 21 & 74 & 5476 \\
\hline 25 & 2 & 1 & 21 & 76 & 5776 \\
\hline 26 & 2 & 1 & 21 & 72 & 5184 \\
\hline 27 & 2 & 1 & 21 & 60 & 3600 \\
\hline 28 & 2 & 1 & 21 & 74 & 5476 \\
\hline 29 & 2 & 1 & 21 & 75 & 5625 \\
\hline 30 & 2 & 1 & 21 & 70 & 4900 \\
\hline 31 & 2 & 2 & 22 & 65 & 4225 \\
\hline 32 & 2 & 2 & 22 & 66 & 4356 \\
\hline 33 & 2 & 2 & 22 & 68 & 4624 \\
\hline 34 & 2 & 2 & 22 & 67 & 4489 \\
\hline 35 & 2 & 2 & 22 & 77 & 5929 \\
\hline
\end{tabular}




\begin{tabular}{|c|c|c|c|c|c|}
\hline 36 & 2 & 2 & 22 & 76 & 5776 \\
\hline 37 & 2 & 2 & 22 & 74 & 5476 \\
\hline 38 & 2 & 2 & 22 & 76 & 5776 \\
\hline 39 & 2 & 2 & 22 & 74 & 5476 \\
\hline 40 & 2 & 2 & 22 & 77 & 5929 \\
\hline
\end{tabular}

\section{Keterangan :}

$\mathrm{A}_{1} \mathrm{~B}_{1} \quad$ : Sikap mahasiswa terhadap aliran Liberalisme, yang berlatar belakang pendidikan pesantren dan yang memiliki pemahaman tinggi pada matakuliah ASWAJA

$\mathrm{A}_{1} \mathrm{~B}_{2} \quad$ : Sikap mahasiswa terhadap aliran Liberalisme, yang berlatar belakang pendidikan pesantren dan yang memiliki pemahaman rendah pada matakuliah ASWAJA

$\mathrm{A}_{2} \mathrm{~B}_{1} \quad$ : Sikap mahasiswa terhadap aliran Liberalisme yang berlatar belakang pendidikan non-pesantren dan yang memiliki pemahaman tinggi pada matakkuliah ASWAJA

$\mathrm{A}_{2} \mathrm{~B}_{2} \quad$ : Sikap mahasiswa terhadap aliran Liberalisme, yang berlatar belakang pendidikan non-pesantren dan yang memiliki pemahaman rendah pada matakkuliah ASWAJA

\section{Desain Penelitian}

Penelitian ini merupakan jenis penelitian yang menggunakan desain varian/ faktorial 2 jalur (ANAVA dua jalur) (Hadjar,2014: 322\&324). 


\begin{tabular}{|c|c|c|c|}
\hline $\mathrm{A}$ & $A_{1}$ & $A_{2}$ & $\Sigma_{\mathrm{B}}$ \\
\hline$B_{1}$ & $\mathrm{~A}_{1} \mathrm{~B}_{1}$ & $\mathrm{~A}_{2} \mathrm{~B}_{1}$ & \\
\hline$B_{2}$ & $\mathrm{~A}_{1} \mathrm{~B}_{2}$ & $\mathrm{~A}_{2} \mathrm{~B}_{2}$ & \\
\hline$\Sigma_{\mathrm{K}}$ & & & \\
\hline
\end{tabular}

A : Latar Belakang Pendidikan (Pesanteren dan NonPesanteren)

B : Pemahaman Matakuliah ASWAJA (Moderat dan Fanatik)

\section{Penghitungan Skor Rata-Rata Sikap Mahasiswa terhadap Liberalisme}

Tabel 2.

Skor Rata-Rata Sikap Mahasiswa terhadap Aliran Liberalisme

\begin{tabular}{|c|c|c|c|}
\hline B & $\begin{array}{c}\quad A_{I} \\
\text { (Pendidikan Pesanteren) }\end{array}$ & $\begin{array}{c}A_{2} \\
\text { (Pendidikan Non-Pesanteren) }\end{array}$ & $\Sigma_{\mathrm{B}}$ \\
\hline $\begin{array}{c}\boldsymbol{B}_{\boldsymbol{I}} \\
\text { (Pemahaman Tinggi) }\end{array}$ & $\begin{aligned} & \mathrm{N}_{11}=10 \\
& \sum \mathrm{Y}_{11}=652 \\
&\left(\sum \mathrm{Y}_{11}\right)^{2}=425104 \\
& \sum \mathrm{Y}_{11}^{2}=42832 \\
& \mathrm{y}_{11}=65,20\end{aligned}$ & $\begin{array}{l}\mathrm{N}_{21}=10 \\
\sum \mathrm{Y}_{21}=722 \\
\left(\sum \mathrm{Y}_{21}\right)^{2}=521284 \\
\sum \mathrm{Y}_{21}^{2}=52336 \\
\mathrm{y}_{21}=72,20\end{array}$ & $\begin{array}{l}\mathrm{N}_{\mathrm{b} 1}=20 \\
\sum \mathrm{Y}_{\mathrm{b} 1}=1374 \\
\left(\sum \mathrm{Y}_{\mathrm{b} 1}\right)^{2}=1887876 \\
\sum \mathrm{Y}_{\mathrm{b} 1}^{2}=95168 \\
\mathrm{y}_{\mathrm{b} 1}=68,70\end{array}$ \\
\hline $\begin{array}{c}\boldsymbol{B}_{2} \\
\text { (Pemahaman rendah) }\end{array}$ & $\begin{aligned} & \mathrm{N}_{12}=10 \\
& \sum \mathrm{Y}_{12}=730 \\
&\left(\sum \mathrm{Y}_{12}\right)^{2}=532900 \\
& \sum \mathrm{Y}_{12}^{2}=53366 \\
& \mathrm{y}_{12}=73,00\end{aligned}$ & $\begin{array}{l}\quad \mathrm{N}_{22}=10 \\
\sum \mathrm{Y}_{22}=720 \\
\left(\sum \mathrm{Y}_{22}\right)^{2}=518400 \\
\sum \mathrm{Y}_{22}^{2}=52056 \\
\mathrm{y}_{22}=72.00\end{array}$ & $\begin{array}{l}\quad \mathrm{N}_{\mathrm{b} 2}=20 \\
\sum \mathrm{Y}_{\mathrm{b} 2}=1450 \\
\left(\sum \mathrm{Y}_{\mathrm{b} 2}\right)^{2}=2102500 \\
\sum \mathrm{Y}_{\mathrm{b} 2}^{2}=105422 \\
\mathrm{y}_{\mathrm{b} 2}=72.50\end{array}$ \\
\hline
\end{tabular}


Pengaruh Latar Belakang

\begin{tabular}{|l|l|l|l|}
\hline$\Sigma_{\mathrm{A}}$ & $\mathrm{N}_{\mathrm{a} 2}=20$ & $\mathrm{~N}_{\mathrm{a} 2}=20$ & $\mathrm{~N}_{\mathrm{t}}=40$ \\
& $\sum \mathrm{Y}_{\mathrm{a} 2}=1382$ & $\sum \mathrm{Y}_{\mathrm{a} 2}=1442$ & $\sum \mathrm{Y}_{\mathrm{t}}=2824$ \\
& $\left(\sum \mathrm{Y}_{\mathrm{a} 2}\right)^{2}=1909924$ & $\left(\sum_{\mathrm{a} 2}\right)^{2}=2079364$ & $\left(\sum \mathrm{Y}_{\mathrm{t}}\right)^{2}=7974976$ \\
& $\sum \mathrm{Y}_{\mathrm{a} 2}^{2}=96198$ & $\sum \mathrm{Y}_{\mathrm{a} 2}^{2}=104392$ & $\sum \mathrm{Y}_{\mathrm{t}}^{2}=200590$ \\
& & $\mathrm{y}_{\mathrm{a} 2}=72,10$ & $\mathrm{y}_{\mathrm{t}}=70,60$ \\
& & & \\
\hline
\end{tabular}

\section{Pengujian Hipotesis Penelitian}

Tabel 3.

Hasil Perhitungan ANAVA dua jalur Pengaruh Latar Belakang Pendidikan dan Pemahaman Mata Kuliah ASWAJA terhadap Sikap Toleran Mahasiswa pada Liberalisme

\begin{tabular}{|c|c|c|c|c|c|}
\hline $\begin{array}{c}\text { SUMBER } \\
\text { VARIAN }\end{array}$ & $\begin{array}{c}\text { jumlah } \\
\text { kaudrat } \\
(\boldsymbol{J K})\end{array}$ & $\begin{array}{c}\text { Derajat } \\
\text { Kebersa } \\
\text { maan } \\
(\boldsymbol{d k})\end{array}$ & $\begin{array}{c}\text { Rerata } \\
\text { Kuadrat } \\
(\boldsymbol{R K})\end{array}$ & $\boldsymbol{F}$ & $\begin{array}{c}\text { Taraf } \\
\text { Signifikansi } \\
(\boldsymbol{p})\end{array}$ \\
\hline $\begin{array}{c}\text { Latar belakang } \\
\text { pendidikan (A) }\end{array}$ & 90.000 & 1 & 90.000 & $55,862^{\mathbf{s}}$ & 0,000 \\
\hline $\begin{array}{c}\text { Pemahaman } \\
\text { ASWAJA (B) }\end{array}$ & 1,600 & 1 & 1,600 & $0,993^{\mathbf{s}}$ & 0,326 \\
\hline Interaksi (A*B) & 0,000 & 1 & 0,000 & $0,000^{\mathbf{t s}}$ & 1,000 \\
\hline Dalam & 58,000 & 36 & 1,611 & & \\
\hline Total & 149,600 & 39 & 3,836 & & \\
\hline
\end{tabular}

Keterangan:

s $\quad$ : $\operatorname{signifikan}($ jika $F>p)$ 
ts $\quad$ : tidak signifikan $($ jika $\mathrm{F}<\mathrm{p})$

A*B : Interaksi antara latarbelakang pendidikan dan pemahaman ASWAJA terhadap sikap toleransi pada Liberalisme

\section{ANALISIS DATA DAN PEMBAHASAN}

\section{a. Perbedaan Sikap Mahasiswa terhadap Liberalisme antara mereka yang berlatar belakang Pendidikan Pesantren dan Non-Pesantren}

Pengaruh latar belakang pendidikan, berdasarkan hasil perhitungan ANAVA dua jalur pada Tabel 3 dapat diketahui bahwa $\boldsymbol{F}=55,862>\boldsymbol{p}=0,000$. Maka secara signifikan hipotesis nol $\left(\mathrm{H}_{0}\right)$ ditolak dan hipotesis penelitian $\left(\mathrm{H}_{1}\right)$ diterima. Hal ini berarti latar belakang pendidikan memberi kontribusi positif terhadap sikap toleran mahasiswa. Dengan demikian, temuan ini membuktikan secara keseluruhan sikap mahasiswa pada Liberalisme dipengaruhi oleh latar belakang pendidikan yang mereka peroleh sebelumnya, baik mereka yang berasal dari pendidikan pesanteren maupun non-pesanteren.

\section{b. Perbedaan Sikap Mahasiswa terhadap Liberalisme antara mereka yang pemhamanya tinggi dan rendah pada Mata Kuliah ASWAJA.}

Pengaruh pemahaman pada mata kuliah ASWAJA, berdasarkan hasil perhitungan ANAVA dua jalur pada Tabel 3 diatas terbukti secara signifikan dengan $\boldsymbol{F}=0,993$ $>\boldsymbol{p}=0,326 \mathrm{Hal}$ ini berarti pemahaman pada mata kuliah ASWAJA memberi kontribusi positif terhadap sikap mahasiswa. Temuan ini juga membuktikan bahwa secara keseluruhan sikap mahasiswa pada aliran Liberalisme dipengaruhi oleh pemahaman mereka terhadap mata kuliah ASWAJA.

Untuk membuktikan latar belakang pendidikan yang manakah (pesantren atau non-pesanteren) yang secara efektif memberikan sumbangan bagi terbentuknya pemahaman yang tinggi atau yang rendah, maka dilakukan Uji-Scheffe. Tabel 4 berikut memberikan temuan informasi tentang perbedaan perlakuan antar kelompok. 
Tabel 4

Hasil Uji-Scheffe untuk Perbedaan Rata-rata

Sikap Mahasiswa terhadap Aliran Liberalisme

\begin{tabular}{|c|c|c|c|}
\hline $\begin{array}{l}\text { Perbandingan Antar } \\
\text { Kelompok }\end{array}$ & $\begin{array}{l}\text { Perbedaan Rerata Antar } \\
\text { Kelompok }\end{array}$ & $\mathrm{F}$ & $\begin{array}{l}\text { Taraf Signifikansi } \\
\text { (p) }\end{array}$ \\
\hline \multicolumn{4}{|c|}{ Efek Utama Faktor A: Latarbelakang Pendidikan } \\
\hline $\begin{array}{c}\text { Pesantren }\left(\mathrm{A}_{1}\right)-\text { Non } \\
\text { Pesantren }\left(\mathrm{A}_{2}\right)\end{array}$ & $66,10-63,10=3,00$ & 55,862 & 0,000 \\
\hline \multicolumn{4}{|c|}{ Efek Utama Faktor B: Tingkat Pemahaman ASWAJA } \\
\hline Tinggi $\left(\mathrm{B}_{1}\right)-$ Rendah $\left(\mathrm{B}_{2}\right)$ & $64,60-64,80=-0,40$ & 0,993 & 0,236 \\
\hline \multicolumn{4}{|c|}{ Efek Interaksi Faktor A dan Faktor B } \\
\hline$\left(\mathrm{A}_{1} \mathrm{~B}_{1}\right)-\left(\mathrm{A}_{1} \mathrm{~B}_{2}\right)$ & $65,900-66,300=-0,400$ & 0,497 & 0,687 \\
\hline$\left(\mathrm{A}_{1} \mathrm{~B}_{1}\right)-\left(\mathrm{A}_{2} \mathrm{~B}_{1}\right)$ & $65,900-62,900=3,000$ & 27,931 & 0,004 \\
\hline$\left(\mathrm{A}_{1} \mathrm{~B}_{1}\right)-\left(\mathrm{A}_{2} \mathrm{~B}_{2}\right)$ & $65,900-63,300=2,600$ & 36,234 & 0,001 \\
\hline$\left(\mathrm{A}_{1} \mathrm{~B}_{2}\right)-\left(\mathrm{A}_{2} \mathrm{~B}_{1}\right)$ & $66,300-62,900=3,400$ & 35,876 & 0,001 \\
\hline$\left(\mathrm{A}_{2} \mathrm{~B}_{1}\right)-\left(\mathrm{A}_{2} \mathrm{~B}_{2}\right)$ & $62,900-63,300=-0,400$ & 0,662 & 0,641 \\
\hline
\end{tabular}

Berdasarkan Tabel 4 tersebut di atas, bahwa efek utama faktor A (Latarbelakang Pendidikan ) ditemukan $\mathbf{F}=55,862>\mathbf{p}=0,000$ terbukti signifikan. Hal ini berarti bahwa latarbelakang pendidikan mempengaruhi sikap moderat (toleran) terhadap Liberalisme. Demikian juga pada efek utama faktor B (Tingkat pemahaman ASWAJA) ditemukan $\mathbf{F}=0,993>\mathbf{p}=0,236$ terbukti signifikan. Hal ini berarti bahwa tingkat pemahaman ASWAJA mempengaruhi sikap fanatik (intoleran) terhadap Liberalisme.

Pada kelompok $\mathrm{A}_{1} \mathrm{~B}_{1}$ (Latarbelakang pendidikan pesantren dengan tingkat pemahaman ASWAJA Tinggi) dan kelompok $\mathrm{A}_{1} \mathrm{~B}_{2}$ (Latar belakang pendidikan pesantren dengan pemahaman ASWAJA rendah) ditemukan $\mathbf{F}=0,497<\mathbf{p}=0,657$ terbukti tidak signifikan. Hal ini berarti latar belakang pendidikan pesantren tidak mempengaruhi tingkat tingginya pemahaman ASWAJA (moderat) dan latarbelakang pendidikan pesantren tidak mempengaruhi pemahaman rendah (fanatik) ASWAJA. 
Untuk kelompok $A_{1} B_{1}$ (latarbelakang pendidikan pesantren dan tingkat pemahaman ASWAJA yang tinggi ) dan $\mathrm{A}_{2} \mathrm{~B}_{1}$ (Latarbelakang non pesantren dengan tingkat pemahaman ASWAJA tinggi) ditemukan $\mathbf{F}=27,931>\mathbf{p}=0,004$ terbukti signifikan. Hal ini berarti bahwa pemahaman tinggi pada mata kuliah ASWAJA, dipengaruhi oleh latar belakang pesantren maupun yang non-pesantren.

Untuk kelompok $\mathrm{A}_{1} \mathrm{~B}_{1}$ (Latarbelakang pendidikan pesantren dengan pemahaman ASWAJA yang tinggi) dan $\mathrm{A}_{2} \mathrm{~B}_{2}$ (latarbelakang pendidikan non pesantren dengan tingkat pemahaman ASWAJA yang rendah) ditemukan $\mathrm{F}=36,324$ > $\mathrm{p}=0,001$ terbukti sangat signifikan. Hal ini berarti bahwa terdapat perbedaan pemahaman antara mahasiswa yang toleran dengan yang intoleran pada mata kuliah ASWAJA, baik mereka yang berpendidikan pesanteren maupun yang non-pesanteren.

Untuk $A_{1} B_{2}$ (latarbelakang pendidikan pesantren dengan tingkat pemahaman ASWAJA yang rendah) dan $\mathrm{A}_{2} \mathrm{~B}_{1}$ (latarbelakang pendidikan non pesantren dengan tingkat pemahaman ASWAJA yang tinggi) ditemukan $\mathrm{F}=35,876>\mathrm{p}=0,001$ terbukti sangat signifikan. Hal ini berarti bahwa latarbelakang pendidikan pesantren dan non pesantren mempengaruhi pemahaman ASWAJA yang tinggi dan rendah.

Untuk kelompok $\mathrm{A}_{2} \mathrm{~B}_{1}$ (Latarbelakang pendidikan non pesantren dengan tingkat pemahaman ASWAJA yang tinggi) dan $\mathrm{A}_{2} \mathrm{~B}_{2}$ (latarbelakang pendidikan non pesantren dengan tingkat pemahaman ASWAJA yang rendah) ditemukan $\mathrm{F}=0,662>$ $\mathrm{p}=0,641$ terbukti sangat signifikan. Hal ini berarti bahwa latarbelakang pendidikan non pesantren mempengaruhi pemahaman ASWAJA yang tinggi dan rendah.

\section{c. Pengaruh Interaksi antara latar belakang Pendidikan dengan Pemahaman pada Mata Kuliah ASWAJA.}

Untuk interaksi antara latar belakang pendidikan dan pemahaman pada mata kuliah ASWAJA, hasil perhitungan sebagaimana pada Tabel 3 di atas menunjukkan bahwa $\boldsymbol{F}=0.000<\boldsymbol{p}=1,00$ terbukti tidak signifikan. Oleh karena itu, hipotesis nol $\left(\mathrm{H}_{0}\right)$ diterima dan hipotesis penelitian $\left(\mathrm{H}_{1}\right)$ ditolak. Hal ini berarti tidak terdapat interaksi antara latar belakang pendidikan (pesanteren dan non-pesanteren) dengan 
tinggi-rendahnya pemahaman mata kuliah ASWAJA. Temuan ini juga membuktikan bahwa toleransi Liberalisme dipengaruhi oleh latarbelakang pendidikan dan tingkat pemahaman ASWAJA.

\section{Kesimpulan}

Dari hasil pembahasan dan analisis diatas, maka diperoleh kesimpulan bahwa latarbelakang pendidikan memberi kontribusi yang singnifikan terhadap sikap toleransi atas Liberalisme. Temuan ini juga membuktikan bahwa sikap toleransi Liberalisme dipengaruhi oleh latarbelakang pendidikan baik pesantren maupun non pesantren.

Pemahaman mata kuliah ASWAJA memberi kontribusi positif terhadap sikap toleran terhadap Liberalisme. Temuan ini membuktikan bahwa toleransi terhadap Liberalisme dipengaruhi oleh pemahaman mata kuliah ASWAJA baik tinggi maupun rendah

Tidak terdapat hubungan interaktif antara latarbelakang pendidikan pesantren dan non pesantren dengan tingkat pemahaman mata kuliah ASWAJA. Dengan demikian, meskipun latarbelakang pendidikan dan tingkat pemahaman ASWAJA memberikan kontribusi yang signifkan pada sikap toleran Liberalisme tetapi antara keduanya tidak terdapat interaksi, sehingga tidak akan memberikan kontribusi yang signifikan pada latarbelakang pendidikan (pesantren dan non pesantren) dan tingkan pemahaman ASWAJA

\section{Daftar Pustaka}

A'la, Abd, 2003, Dari Neo-modernisme ke Islam Liberal, Jakarta : Dian Rakyat (Paramadina)

al-Khurasyi, Sulaim bin Saleh,2010, Haqiqah al-Libraliyah wa Mauqif al-Islam minha.

Hadjar, Ibnu, 2014, Dasar-dasar Statistik untuk Ilmu Pendidikan Sosial \& Humanoria, Semarang : Pustaka Zaman

Muchtar, Masyhudi dkk, 2007, ASWAJA an-Nahdliyah ; Ajaran Ahlusunnah wa alJama'ah yang Berlaku di Lingkungan Nahdlatul Ulama, Surabaya: Khalista. 
Rakhmat, Jalaludin, 2008, Psikologi Komunikasi, Bandung : PT Rosydakarya

Thaha, Anis Malik, 2002, Tren Pluralisme Agama, Jakarta : Perspektif

Wahid, Salahuddin, 2011, Transformasi Pesantren Tebuireng: Menjaga Tradisi di Tengah Tantangan, Malang: UIN Maliki Press 